\title{
SMOKE FEE CAMPAIGN THROUGH SCHOOL-BASED PREVENTION PROGRAM AT MUTIARA HARAPAN ISLAMIC SCHOOL, TANGERANG - BANTEN
}

\author{
Yufitri Mayasari $^{1 *}$, Wulan Apridita Sebastian ${ }^{1}$, Mutiara Rina RR ${ }^{1}$ \\ ${ }^{1}$ Department of Community Dental Health Sciences Faculty of Dentistry \\ Prof. Dr. Moestopo (Beragama) University \\ *yufitrimayasari@gmail.com
}

\begin{abstract}
Abstrak - Children are susceptible to be passive smokers as a consequence of exposure to cigarette smoke when they are in the surroundings of smokers. Nearly $70 \%$ of children aged 13-15 years are exposed to cigarette smoke inside their homes, while 78 percent are exposed to cigarettes outside their homes. Cigarette smoke has a bad impact on health in children, even though they do not understand the dangers of cigarette smoke. For this reason, an extension activity is conducted on the dangers of cigarette smoke, so that children can understand the dangers of cigarette smoke and can be the main driver for parents and their surroundings to live smoke-free.
\end{abstract}

Keywords: Cigarette smoke, passive smokers, dangers of smoking

\section{INTRODUCTION}

World Health Organization (WHO) states that Indonesia is one of the countries with the highest prevalence of smokers in the world. The proportion of active smokers in Indonesia, increasing from year to year [1], amounts to nearly 63 million smokers [2]. The most vulnerable population to start smoking is in the period of children or adolescents. According to the World Bank, every day there are nearly 82,000-99,000 children and adolescents around the world who start smoking [3].

The increasing number of active smokers has an impact on increasing the prevalence of passive smokers. The same big potential risk will be encountered by active smokers as a consequence of being in a surroundings of smokers, such as heart disease, lung cancer and other respiratory disorders. The most vulnerable age group to be passive smokers is the age of $13-15$ years. Nearly $70 \%$ are exposed to cigarette smoke inside their homes, while 78 percent of the children are exposed to cigarette smoke outside their homes [4].

Although some studies have shown that smoking bans at home are associated with smokers' awareness of the presence of second-hand smoke which is harmful to both non-smokers and the household environment, more than $90 \%$ of parents agree that parents who smoke give a bad impact on their family's health, especially exposure to cigarette smoke in children. However, there are differences in awareness of the dangers of cigarette smoke due to several factors such as education level, age, and gender. ${ }^{5}$ The theory of Health Belief Model shows that a person can be motivated in changing proactive behavior in an effort to avoid negative consequences for his health $[5,6]$.

Cigarette smoke has a bad impact on public health, especially in children. They still do not understand the dangers of cigarette smoke so extension activity is conducted so that children can understand the dangers of cigarette smoke and can be the main driver of parents and the surroundings to live smoke-free.

With regard to the above description, the activity of Community Service held by the lecturers of the Faculty of Dentistry, University of Prof. Dr. Moestopo (Beragama) aims to: (1) find out the adverse effects of cigarettes and cigarette smoke on the body health, especially the teeth and mouth; (2) be able to make efforts to avoid exposure to cigarette smoke; (3) be able to take action for the surrounding environment to live smoke-free. 
In the long run, this activity is expected to reduce the number of diseases caused by the exposure to cigarette smoke in the community, especially children, so this activity is named: "Campaign for Smoke-Free Kids through Oral Health School Program". This activity took place at Mutiara Harapan Islamic School, Tangerang, in early April 2018 with the target of students from grade one to grade six with a total of 180 students.

\section{METHOD}

This activity used a face-to-face method (lecture) in front of the students which was then followed by demonstrations. During the demonstration, props were used including cigarette models, posters and videos so that students could understand deeply the dangers of smoking to health.

Face-to-face method was carried out using simple language, accompanied by utterances in the form of children's typical cheerfulness, so that effective forms of communication were established for children. With such a communication model, messages conveyed about the dangers of smoking were expected to be embedded in their memory and they could remember them until adulthood.

\section{RESULT AND DISCUSSION}

Extension activity regarding the dangers of cigarette smoke to health was carried out for one day. The event was opened with a speech from the committee chairman and from the Mutiara Harapan Islamic School, Tangerang. Education provided was in the form of negative impacts from exposure to cigarette smoke using props that was a replica of cigarettes along with large cigarette packs, videos, and flags with smoke-free images. The event was closed by giving a questionnaire to evaluate students' knowledge, awareness and behavior towards the dangers of cigarette smoke.

Students of Mutiara Harapan Islamic School had high enthusiasm when participating in this activity and many of them agreed to avoid the exposure to cigarette smoke. The school is committed to continuing to support this program and make the school smoke-free.

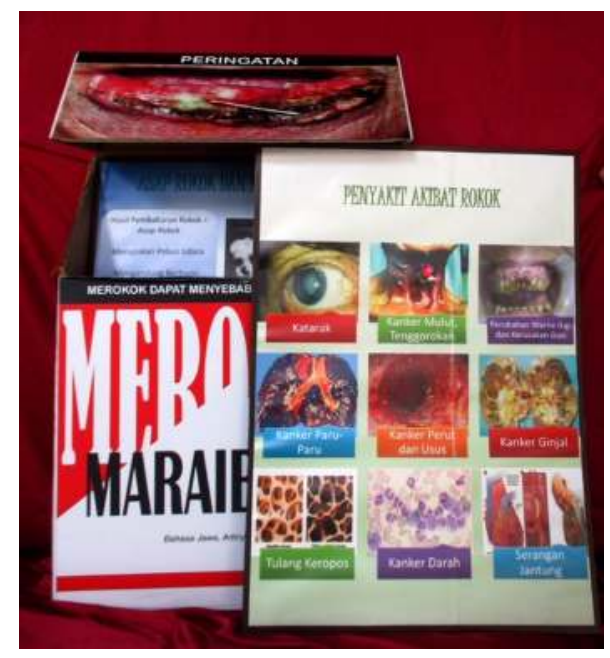

Figure 1. Cigarette Poster in the form of a Cigarette Box

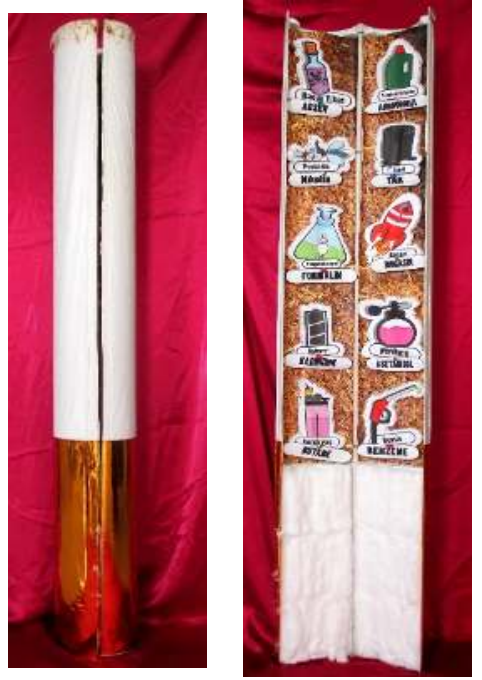

Figure 2. Cigarette models containing harmful ingredients that emit smoke

Meanwhile, the evaluation of the extension activity was conducted by giving questionnaires to find out the knowledge, awareness and actions of students on the dangers of cigarette smoke. 


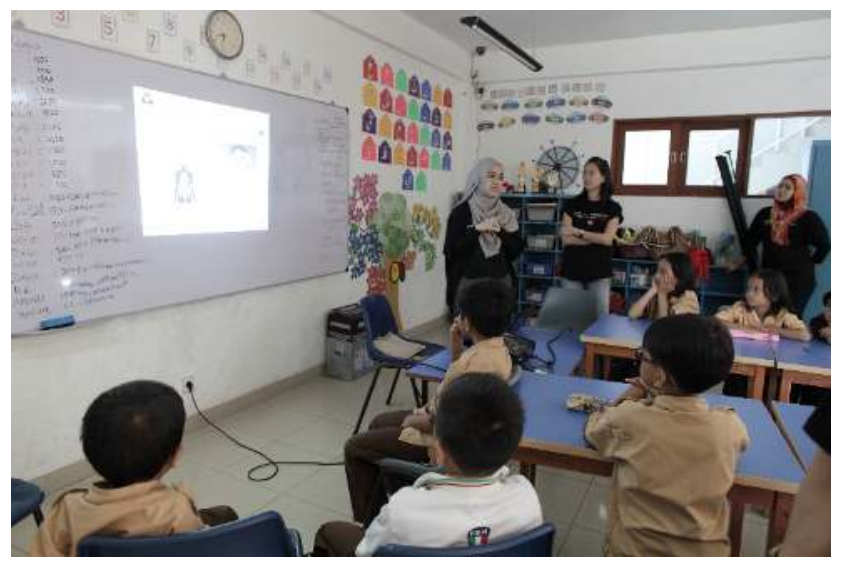

Figure 3. Education on the dangers of cigarette smoke
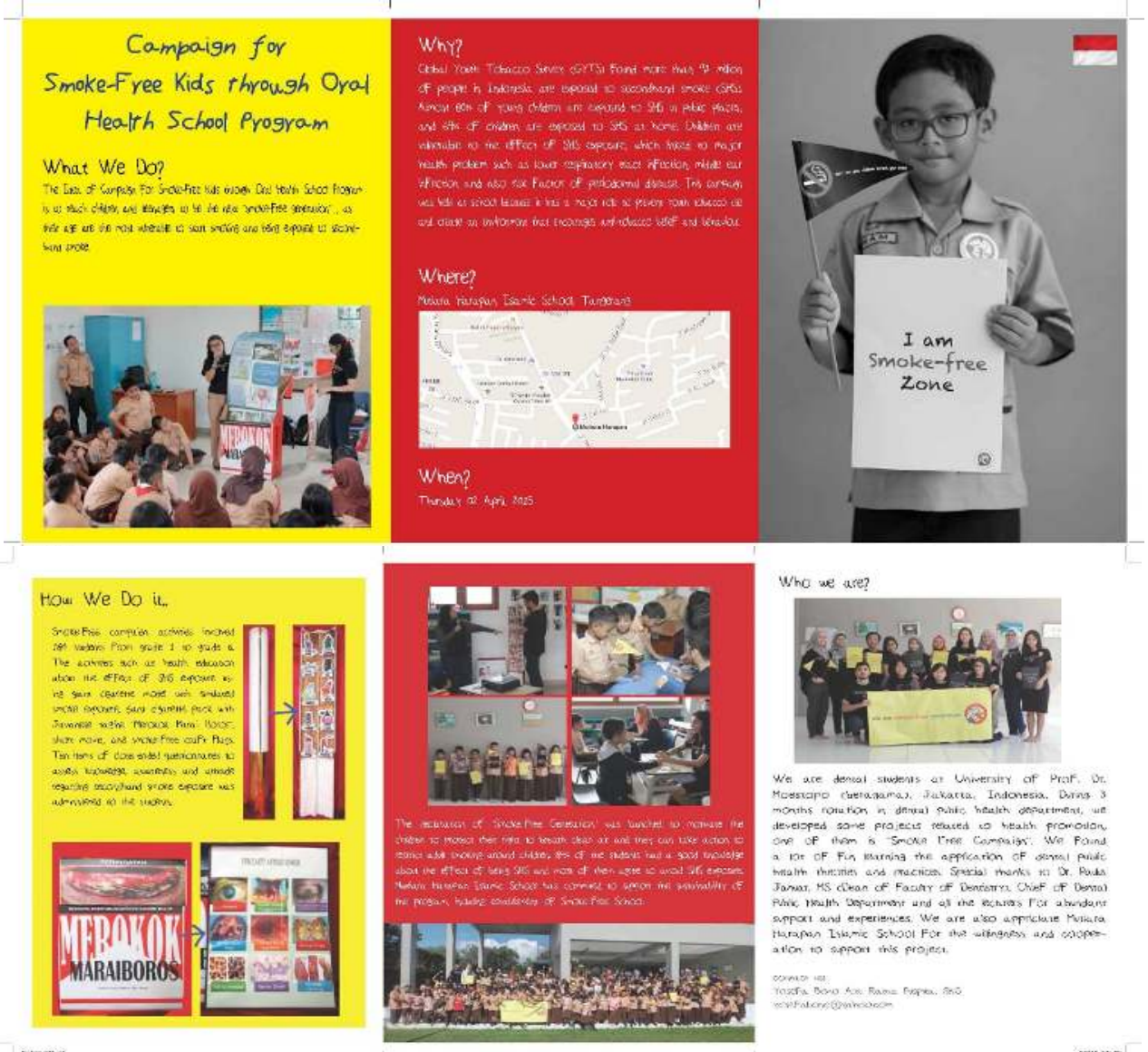

Figure 4. Event Flyer

\section{CONCLUSION}

This extension program went well proven by the enthusiasm of the students and the community of Mutiara Harapan Islamic School which was quite high so that the information provided could be 
absorbed properly. Methods and props are one of the important factors in delivering education so students are interested in listening and absorbing the information provided.

Suggestions obtained from this activity are conducting educational activities on the dangers of cigarette smoke to other schools and using other props that can further hone children's affective, psychometric and cognitive aspects so that information can be applied in everyday life.

\section{REFERENCES}

Riset Kesehatan Dasar. Riset Kesehatan Dasar (Riskesdas) 2013. In: Badan Penelitian dan Pengembangan Kesehatan Kementerian Kesehatan RI. , editor. 2013

Reimondos A, Utomo ID, McDonald P, Hull T, Suparno H, Utomo A. Smoking and Young Adults in Indonesia. 2010.

Chadda, R. K., \& Sengupta, S. N. (2002). Tobacco use by Indian adolescents. Tobacco induced diseases, 1(2), 111-119

WHO (World Health Organization). Indonesia (Ages 13-15), Global Youth Tobacco Survey (GYTS) Fact Sheet. 2009.

Drehmer JE, Ossip DJ, Nabi-Burza E, Rigotti NA, Hipple B, Woo H, et al. Thirdhand Smoke Beliefs of Parents. Pediatrics. 2014;133(4):e850-e6.

Green EC, Murphy E. Health belief model. The Wiley Blackwell Encyclopedia of Health, Illness, Behavior, and Society. 2002.

Riset Kesehatan Dasar. Riset Kesehatan Dasar (Riskesdas) 2013. In: Badan Penelitian dan Pengembangan Kesehatan Kementerian Kesehatan RI. , editor. 2013.

Reimondos A, Utomo ID, McDonald P, Hull T, Suparno H, Utomo A. Smoking and Young Adults in Indonesia. 2010.

Chadda, R. K., \& Sengupta, S. N. (2002). Tobacco use by Indian adolescents. Tobacco induced diseases, 1(2), 111-119

WHO (World Health Organization). Indonesia (Ages 13-15), Global Youth Tobacco Survey (GYTS) Fact Sheet. 2009.

Drehmer, J. E., Ossip, D. J., Nabi-Burza, E., Rigotti, N. A., Hipple, B., Woo, H., ... \& Winickoff, J. P. Thirdhand Smoke Beliefs of Parents. Pediatrics. 2014;133(4):e850-e6.

Green EC, Murphy E. Health belief model. The Wiley Blackwell Encyclopedia of Health, Illness, Behavior, and Society. 2002. 